University of Wollongong

Research Online

Australian Institute for Innovative Materials -

Papers

Australian Institute for Innovative Materials

$1-1-2011$

Dithienothiophene (DTT)-based dyes for dye-sensitized solar cells: synthesis of 2,6-Dibromo-DTT

\author{
Tae-Hyuk Kwon \\ University of Melbourne \\ Vanessa Armel \\ Monash University \\ Andrew Nattestad \\ University of Wollongong, anattest@uow.edu.au \\ Douglas R. MacFarlane \\ Monash University, douglas.macfarlane@monash.edu.au \\ Udo Bach \\ Monash University
}

See next page for additional authors

Follow this and additional works at: https://ro.uow.edu.au/aiimpapers

Part of the Engineering Commons, and the Physical Sciences and Mathematics Commons

Research Online is the open access institutional repository for the University of Wollongong. For further information contact the UOW Library: research-pubs@uow.edu.au 


\title{
Dithienothiophene (DTT)-based dyes for dye-sensitized solar cells: synthesis of 2,6-Dibromo-DTT
}

\begin{abstract}
A one-pot synthesis of 2,6-dibromodithieno[3,2-b;2',3'-d]thiophene (dibromo-DTT, 4) was developed. A key step was bromodecarboxylation of DTT-2,6-dicarboxylic acid, obtained by saponification of the diester 1 . The donor-acceptor dye DAHTDTT (13), based on a central 2,6-bis[2'-(3'-hexylthienyl)]dithieno[3,2-b;2',3'd]thiophene core (9), was prepared and incorporated in a dye-sensitized solar cell (DSC), which exhibited an energy conversion efficiency of $7.3 \%$ with Voc of $697 \mathrm{mV}$, Jsc of $14.4 \mathrm{~mA} / \mathrm{cm} 2$, and ff of 0.73 at 1 sun.
\end{abstract}

\section{Keywords}

cells, solar, sensitized, dye, dyes, dithienothiophene, dtt, dibromo, 6, 2, synthesis

\section{Disciplines}

Engineering | Physical Sciences and Mathematics

\section{Publication Details}

Kwon, T., Armel, V., MacFarlane, D. R., Bach, U., Lind, S. L., Gordon, K., Tang, W., Jones, D. J. \& Holmes, A. B. (2011). Dithienothiophene (DTT)-based dyes for dye-sensitized solar cells: synthesis of 2,6-Dibromo-DTT. Journal of Organic Chemistry, 76 (10), 4088-4093.

\section{Authors}

Tae-Hyuk Kwon, Vanessa Armel, Andrew Nattestad, Douglas R. MacFarlane, Udo Bach, Samuel J. Lind, Keith C. Gordon, Weihua Tang, David J. Jones, and Andrew Holmes 


\section{Dithienothiophene (DTT)-based Dyes for Dye- Sensitized Solar Cells: Synthesis of 2,6-Dibromo- DTT.}

Tae-Hyuk Kwon, ${ }^{\dagger}$ Vanessa Armel, ${ }^{\ddagger}$ Andrew Nattestad, ${ }^{\ddagger}$ Douglas R. MacFarlane, ${ }^{*, *}$ Udo Bach, ${ }^{*, \neq}$ Samuel J. Lind, ${ }^{\S}$

Keith C. Gordon, ${ }^{\S}$ Weihua Tang, ${ }^{\dagger}$ David J. Jones, ${ }^{\dagger}$ and Andrew B. Holmes*, ${ }^{\dagger}$

${ }^{\dagger}$ School of Chemistry, Bio21 Institute, University of Melbourne, Parkville, Vic 3010, Australia, ${ }^{\ddagger}$ ARC Centre of Excellence for Electromaterials Science, Monash University, Clayton, Vic 3800, Australia, and ${ }^{\S}$ MacDiarmid Institute for Advanced Materials and Nanotechnology, Department of Chemistry, University of Otago, Dunedin, New Zealand..

aholmes@unimelb.edu.au, Douglas.MacFarlane@monash.edu, Udo.Bach@sci.monash.edu.au

\section{RECEIVED DATE (will be automatically inserted after manuscript is accepted).}

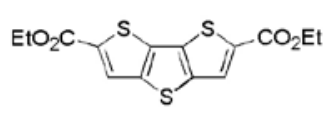

1

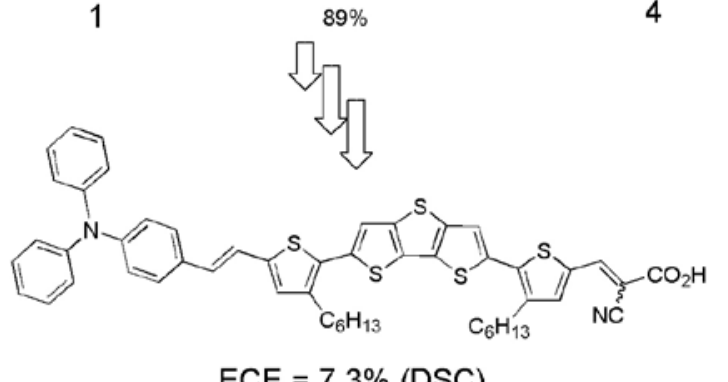

$\mathrm{ECE}=7.3 \%(\mathrm{DSC})$

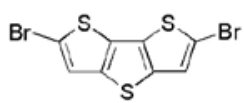

4 fragment (A) to achieve broad and intense absorption within the visible to near IR spectrum. When designing dyes for high efficiency DSCs, it is preferable to (i) employ a non-planar structure to prevent self-aggregation, (ii) incorporate appropriate conjugation length for a broad absorption, (iii) use long alkyl chain substituents to minimize electron recombination, (iv) aim for chemical and structural stability.

In this study, we employ a 2,6-bis[2'-(3'-

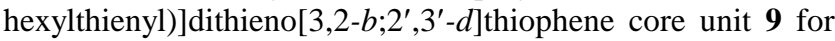
the $\pi$-conjugated linking segment. This is due to the relatively high hole mobility exhibited by the fused thiophene $\operatorname{core}^{18}$ in a variety of electronic and optical applications, ${ }^{4,7,19}$ such as organic thin film transistors ${ }^{18,20-22}$ and polymer solar cells. ${ }^{21}$ Owing to the various useful applications of dithieno[3,2$\left.b ; 2^{\prime}, 3^{\prime}-d\right]$ thiophene (DTT) in the optoelectronic field, the synthesis of DTT derivatives has received much attention. ${ }^{23-25}$ However many approaches still require multiple steps and harsh conditions. ${ }^{23,24}$ For the purpose of a convenient synthesis and scale up of the DTT unit, we developed a synthesis of 2,6dibromo-DTT 4 by one-pot bromodecarboxylation reaction of the DTT-diacid 5.

SCHEME 1. Routes to dibromo-DTT 4 from the diester 1.

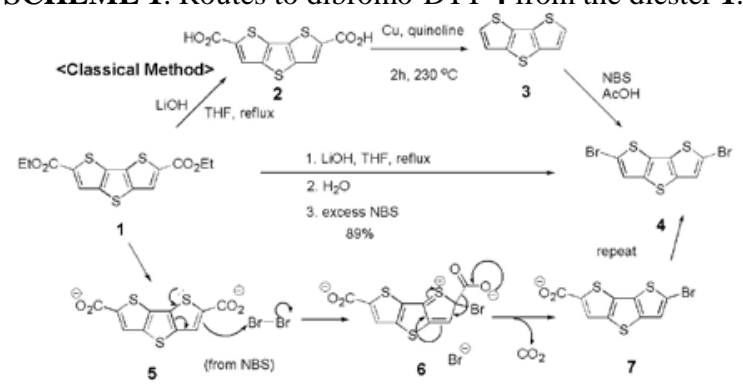

SCHEME 2. Synthesis of the dye 13.

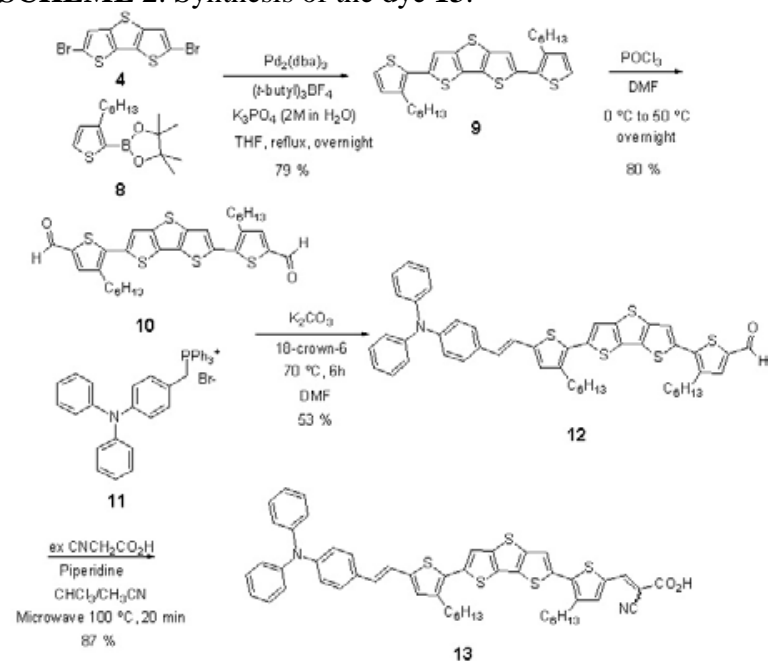

Recently thiophene-based dyes have been used for lightharvesting in DSCs. ${ }^{4-6}$ However, as DTT-based dyes may not exhibit a broad absorption region; ${ }^{6}$ modification of the structure through additional double conjugation by introduction of 3-hexylthiophene units can improve this situation. An additional benefit is the inhibition of electron 
recombination from the $\mathrm{TiO}_{2}$ nanoparticle to the radical cation of the dye owing to the presence of the hexyl substituents. The final components of the light harvesting dye DAHTDTT 13 are the nonplanar triphenyl amine (TPA) donor unit (D) and an $\alpha$-cyanoacrylic acid group as the electron acceptor (A) to form a D- $\pi$-A structure.

The synthesis of the dye DAHTDTT 13 is shown in Scheme 2. 2,6,-Dibromo-DTT 4 can be prepared by bromination of DTT 3, itself obtained by decarboxylation of the diacid 2 (overall yield $40 \%$ for three steps). ${ }^{23,24}$ However, this classical method, although it gave a good yield, still required a three step process and included the harsh preliminary decarboxylation step as outlined in Scheme 1. We now report an improved synthesis of the dibromo-DTT 4 by a one-pot bromo-decarboxylation of the DTT-2,6-diacid $\mathbf{5}$ (Scheme 1). ${ }^{14}$ This method, followed standard saponification of the diester 6 (heat to reflux in aqueous THF containing $\mathrm{NaOH}$ ), dilution of the cooled product slurry to dissolve the carboxylate salt, and addition of an excess of NBS (over 6 eq) followed by stirring overnight. Standard extraction with $\mathrm{CH}_{2} \mathrm{Cl}_{2}$ and basic work-up produced the dibromo-DTT 4 in over $80 \%$ yield.

Without column purification, the dibromo-compound $\mathbf{4}$ was coupled under Suzuki conditions with 3-hexylthiophene-2pinacolylboronate $\mathbf{8}$ in the presence of $\mathrm{Pd}_{2}(\mathrm{dba})_{3}, \quad(t-$ butyl) ${ }_{3} \mathrm{P} . \mathrm{HBF}_{4}$ and $2 \mathrm{M} \quad \mathrm{K}_{3} \mathrm{PO}_{4}$, to afford bis(3hexylthiophenyl)-DTT 9 in 79\% yield. Vilsmeier formylation gave the dialdehyde $\mathbf{1 0}$ which underwent a mono-WittigHorner chain extension in 53\% yield with the ylide derived from the known triarylamine-based phosphonium salt $\mathbf{1 1}^{6}$ Knoevenagel-type condensation of the resulting aldehyde $\mathbf{1 2}$ with cyanoacetic acid ( $>20$ equiv.) in a microwave reactor gave the required dye $\mathbf{1 3}$ in $\mathbf{8 7 \%}$ yield after purification by column chromatography.

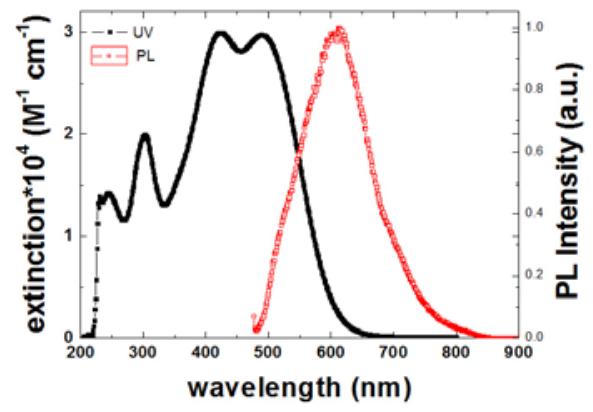

FIGURE 1. UV/VIS and PL spectra of dye 13 in $\mathrm{CH}_{2} \mathrm{Cl}_{2}(0.02 \mathrm{mM})$.

The UV/VIS absorption spectrum of the dye DAHTDTT 13 in $\mathrm{CH}_{2} \mathrm{Cl}_{2}(0.02 \mathrm{mM})$ showed a strong broad absorption maximum around $650 \mathrm{~nm}\left(\varepsilon_{\max }>30,000\right)$, with the $\mathrm{PL}$ emission maximum at $613 \mathrm{~nm}$ as shown in Figure $\mathbf{1}$.

Cyclic voltammetry measurements of the dye 13 in $\mathrm{CH}_{2} \mathrm{Cl}_{2}$ solutions $(0.5 \mathrm{mM})$ with $0.1 \mathrm{M}$ tetra-n-butylammonium hexafluorophosphate $\left(\mathrm{TBAPF}_{6}\right)$ as the supporting electrolyte are summarized in Table 1. Also included are the observed UV/VIS and PL emission spectra and the DFT-calculated HOMO and LUMO energies.
The oxidation potential of the dye $\mathbf{1 3}$ (0.98 V versus NHE) is sufficiently positive compared with the reduction potential of iodine/iodide, ( $0.4 \mathrm{~V}$ versus $\mathrm{NHE}$ ) that the photooxidized dye could be expected to be reduced efficiently by the iodine/iodide redox couple. The reduction potential of the dye $\left(-1.29 \mathrm{~V}\right.$ vs NHE) was calculated from $E_{0 x}-E_{0-0}(\mathrm{~V})$. As this is more negative value than the level of the $\mathrm{TiO}_{2}$ conduction band (CB) edge, (-0.5 V vs NHE) we can expect that the photoexcited state of the dye $\mathbf{1 3}$ can effectively inject electrons into the conduction band (CB) of $\mathrm{TiO}_{2}$.

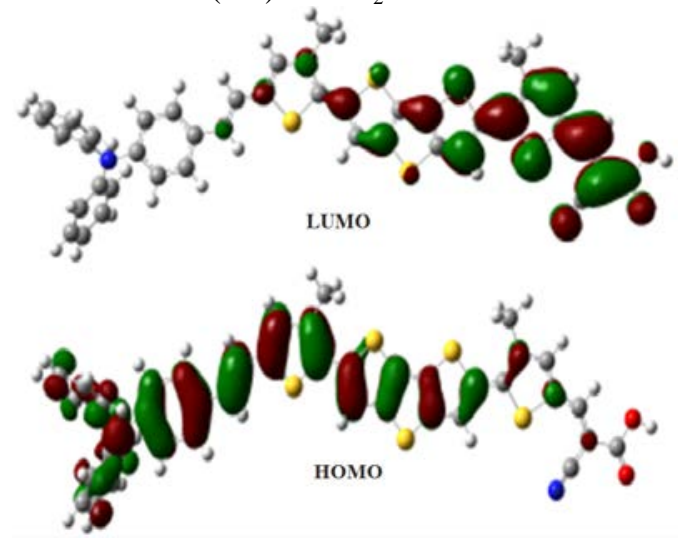

FIGURE 2. DFT-calculated electron densities of HOMO (bottom) and LUMO (top) orbitals of $\mathbf{1 3 .}$

Optimized Density Functional Theory (DFT) calculations were carried out utilizing Gaussian09 at the B3LYP/6-31G(d) level of theory. ${ }^{26}$ As shown in Figure 2, the electron densities in the HOMO and LUMO of the dye are well separated. The HOMO is generally located on the triphenyl amine unit while the LUMO is on the cyanoacetic acid group; this is a desirable feature for the required charge separation in dye-sensitized solar cells.

DSCs were constructed using a sandwich configuration with an electrolyte composed of $0.6 \mathrm{M}$ 1,2-dimethyl-3propylimidazolium iodide, $0.025 \mathrm{M}$ lithium iodide, $0.04 \mathrm{M}$ iodine, 0.05 M guanidinium thiocyanate (GuSCN), and 0.28 M tert-butylpyridine (TBP) in a dry acetonitrile/valeronitrile solvent mixture $(\mathrm{v} / \mathrm{v}=85 / 15) .{ }^{6}$ For the titanium oxide different film thicknesses of the transparent and scattering layer were used as follows: $6 \mu \mathrm{m}(6), 6+6$ scattering layer $\mu \mathrm{m}$ $(6+6 \mathrm{~s}), 12 \mu \mathrm{m}(12)$, and $12+6$ scattering layer $\mu \mathrm{m}(12+6 \mathrm{~s})$ were studied as well as the effect of the co-adsorbent (DCA $=3 \alpha, 7 \alpha$-dihydroxy- $5 \beta$-cholic acid).

The device performances are summarized in Table 2, with optimal results shown in Figure 3 and 4. The dye 13 was adsorbed onto the titania from different solvents. The choice of solvent is crucial, and the device performance varied significantly according to the solvent system chosen. The difference in performance could be due to the interaction of the dye with the solvent, which can affect the photophysical and chemical properties of the dye on the $\mathrm{TiO}_{2}$ surface. ${ }^{6}$ The binding mode and the number of dye molecules adsorbed onto the $\mathrm{TiO}_{2}$ depend on the solvents. Adsorption of the dye $\mathbf{1 3}$ in 
TABLE 1. DFT-calculated HOMO and LUMO energy levels, the experimentally determined values from the electrochemically measured oxidation potential and the optical bandgap, and UV/VIS absorption and PL emission maxima in dichloromethane solution.

\begin{tabular}{|c|c|c|c|c|c|c|c|}
\hline Entry & $\underset{\mathrm{HOMO}_{\mathrm{cal}}}{{ }^{a}}(\mathrm{Exp}$ & $\begin{array}{l}\text { LUMO }_{\text {cal }} \\
\left(\text { Exp }^{a}\right.\end{array}$ & Abs $\left(\varepsilon \times 10^{4} \mathrm{~cm}^{-1} \mathrm{~mol}^{-1}\right)^{b}$ & $\begin{array}{c}\mathrm{PL}^{b} \\
\left(\lambda_{\max }\right)\end{array}$ & $E_{\mathrm{ox}}(\mathrm{V}) \mathrm{vs} \mathrm{NHE}^{c}$ & $\begin{array}{l}E_{\text {o-o }}(\mathrm{V}) \mathrm{vs} \\
(\mathrm{abs} / \mathrm{Em})^{d}\end{array}$ & $E_{\mathrm{ox}}-E_{\mathrm{o}-\mathrm{o}}(\mathrm{V})$ vs NHE \\
\hline Dye 13 & $\begin{array}{c}-4.67 \\
(-5.15)\end{array}$ & $\begin{array}{l}-2.75 \\
(-2.88)\end{array}$ & $\begin{array}{c}301(2.0), 423(3.0), \\
489(3.0)\end{array}$ & $613 \mathrm{~nm}$ & 0.98 & 2.27 & -1.29 \\
\hline
\end{tabular}

${ }^{a} \mathrm{HOMO}=-\left(E_{\text {onset }} \mathrm{Vs} \mathrm{FC}^{+} / \mathrm{FC}-4.8 \mathrm{eV}\right), \mathrm{LUMO}=\mathrm{HOMO}+E_{0-0}{ }^{b} 0.02 \mathrm{mM} \mathrm{CH}_{2} \mathrm{Cl}_{2}$ solution at $298 \mathrm{~K} .{ }^{c}$ Cyclic voltammetry measurement of the onset point of oxidation $E_{o x}$ of the dye were measured in dry $\mathrm{CH}_{2} \mathrm{Cl}_{2}$ containing $0.1 \mathrm{M}$ tetrabutylammonium hexafluorophosphate (TBAPF as supporting electrolyte, $\mathrm{Ag} / \mathrm{AgCl}$ as a reference electrode, and glassy carbon as working electrode. Potentials calibrated with $\mathrm{Fc}^{+} / \mathrm{Fc}_{\mathrm{c}}$ were converted normal hydrogen electrode (NHE) by addition of $+0.63 \mathrm{~V} .{ }^{6}{ }^{d}$ The $E_{0-0}$ transition energy was estimated from the intersection of the absorption and emission spectra.

$\mathrm{CHCl}_{3}$ and EtOH solvent mixtures (1:1) yielded the highest device efficiency compared with $\mathrm{CHCl}_{3}, \mathrm{CH}_{2} \mathrm{Cl}_{2}$, $\mathrm{CH}_{2} \mathrm{Cl}_{2} / \mathrm{EtOH}$, chlorobenzene, and chlorobenzene/EtOH (see ESI). Optimum devices were obtained using the dye $(0.2 \mathrm{mM})$ in $\mathrm{CHCl}_{3} / \mathrm{EtOH}(1 / 1)$ solutions with overnight soaking on titania. Thus all devices were prepared in $0.2 \mathrm{mM}$ $\mathrm{CHCl}_{3} / \mathrm{EtOH}(1 / 1)$ solutions after overnight soaking.

TABLE 2. Photovoltaic performance of cells fabricated using the dye 13.

\begin{tabular}{lllllll}
\hline$\#$ & $\begin{array}{l}\text { Thick } \\
(\mu \mathrm{m})\end{array}$ & $\begin{array}{l}\text { Coads } \\
(\mathrm{mM})\end{array}$ & $\begin{array}{l}V_{\text {oc }} \\
(\mathrm{mV})\end{array}$ & $\begin{array}{l}J_{\text {sc }}(\mathrm{mA} / \mathrm{cm} \\
\text { (f) }\end{array}$ & ff & $\begin{array}{l}\text { Effic } \\
(\%)\end{array}$ \\
\hline 1 & 6 & 0 & 700 & 11.0 & 0.73 & 5.6 \\
2 & 6 & 10 & 718 & 12.2 & 0.74 & 6.5 \\
3 & $6+6 \mathrm{~s}^{b}$ & 10 & 720 & 12.6 & 0.71 & 6.4 \\
4 & 12 & 10 & 705 & 13.3 & 0.70 & 6.6 \\
5 & $12+6 \mathrm{~s}$ & 10 & 698 & 14.7 & 0.70 & 7.1 \\
6 & $12+6 \mathrm{~s}$ & 20 & 697 & 14.4 & 0.73 & 7.3 \\
$\mathrm{~N} 719^{c}$ & $12+6 \mathrm{~s}$ & & 780 & 14.5 & 0.73 & 8.3 \\
\hline
\end{tabular}

${ }^{a}$ Co-adsorbent is $3 \alpha, 7 \alpha$-dihydroxy-5 $\beta$-cholic acid. ${ }^{b} 6 \mathrm{~s}$ is $6 \mu \mathrm{m}$ scattering layer. ${ }^{\circ}$ Electrolyte for N719:0.6 M 1-butyl-3methyl imidazolium iodide, $0.03 \mathrm{M} \mathrm{I}_{2}, 0.10 \mathrm{M}$ guanidinium thiocyanate (GuSCN), and $0.50 \mathrm{M}$-butylpyridine (TBP) in the dry acetonitrile/valeronitrile $(\mathrm{v} / \mathrm{v}=85 / 15)$.

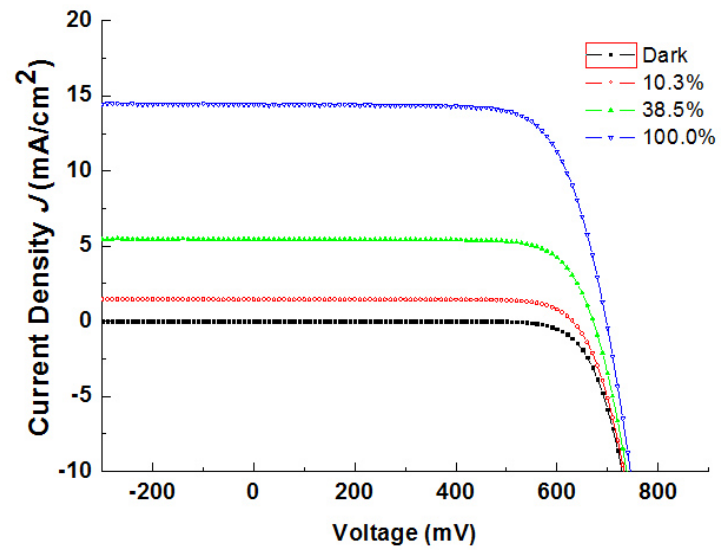

FIGURE 3. The $I$ - $V$ curve of a DSC device using the titania layers 12 $+6 s$ and standard electrolyte under various solar simulated light intensities.

Using a $6 \mu \mathrm{m}$ titania film without any co-adsorbent, a device fabricated with dye $\mathbf{1 3}$ gave a short-circuit photocurrent density $\left(J_{\mathrm{sc}}\right)$ of $11.01 \mathrm{~mA} / \mathrm{cm}^{2}$, an open-circuit voltage $\left(V_{\text {oc }}\right)$ of $700 \mathrm{mV}$, and a fill factor $(\mathrm{ff})$ of 0.73 , corresponding to an overall conversion efficiency $(\eta)$ of $5.6 \%$. With $10 \mathrm{mM}$ DCA as co-adsorbent, the device efficiency was increased up to $6.5 \%\left(V_{\text {ос }}=718 \mathrm{mV}, J_{\text {sc }}=12.2 \mathrm{~mA} / \mathrm{cm}^{2}, f f=0.74\right)$. These results indicate that the co-adsorbent prevents dye-aggregation thus improving electron injection yield. ${ }^{7}$ Adsorption of DCA usually leaves protons on the $\mathrm{TiO}_{2}$ surface and hence positively charges the surface. Thus the conduction band is shifted, resulting in low $V_{\mathrm{oc}}{ }^{7,8}$ However, in the present case an increase of $20 \mathrm{mV}$ was observed, indicating that charge recombination was suppressed by DCA. ${ }^{7}$ With a $6 \mu \mathrm{m}$ scattering layer $(6+6 \mathrm{~s})$, an increase in $J_{\mathrm{sc}}$ from 12.2 to 12.6 $\mathrm{mA} / \mathrm{cm}^{2}$ was obtained. However, with a concomitant decrease in the fill factor from 0.74 to 0.71 , the device efficiency with a $6+6$ s film (6.4\%) was not significantly different from that of a $6 \mu \mathrm{m}$ film (6.5\%). Using a $12 \mu \mathrm{m}$ film thickness, an increase of $J_{\mathrm{sc}}$ to $13.3 \mathrm{~mA} / \mathrm{cm}^{2}$ was observed as well as a loss in $V_{\text {oc }}$ and a reduction in fill factor, resulting in a small increase in perfomance of the cells (6.6\%). Using a $12 \mu \mathrm{m}$ transparent film with a $6 \mu \mathrm{m}$ scattering layer, $12+6 \mathrm{~s}, J_{\mathrm{sc}}$ significantly increased to $14.7 \mathrm{~mA} / \mathrm{cm}^{2}$ while $V_{\text {oc }}$ remained the same $(698$ $\mathrm{mV}$ ) and the fill factor was 0.70 , leading to device efficiency improving to $7.1 \%$. The $J_{\text {sc }}$ of devices made with the dye $\mathbf{1 3}$ is slightly higher than that achieved for N719 $\left(14.5 \mathrm{~mA} / \mathrm{cm}^{2}\right)$ under the same conditions. Through further optimization, via an increase of co-adsorbent ( $20 \mathrm{mM})$, the performance of the cell increased to $7.3 \%$ with $V_{\text {oc }}$ of $697 \mathrm{mV}, J_{\text {sc }}$ of $14.4 \mathrm{~mA} / \mathrm{cm}^{2}$ and fill factor was 0.73 .

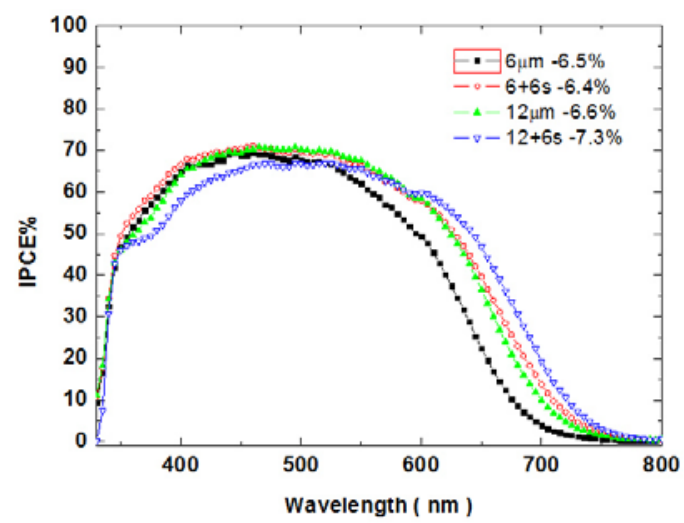

FIGURE 4. IPCE spectrum of devices fabricated using the dye $\mathbf{1 3}$ according to the film thickness of titania.

Compared with the previously reported device performance $(\eta=2.76 \%)$ of a similar dithienothiophene based dye (E)-2Cyano-3-\{6-[2-(4-diphenylamino-phenyl)-vinyl]dithieno[3,2b;2',3'-d]thiophen-2-yl $\}$-acrylic acid TTC2, ${ }^{6}$ the efficiency of device made with dye 13 increases by a factor of $c a 2.6$ under similar electrolyte composition and film thickness. Moreover, this efficiency reached $88 \%$ of the efficiency of devices made with N719 dye $(\eta=8.3 \%)$. Figure 3 shows the detailed current density versus voltage $(I-V)$ curve at different light intensity: $10.3 \%, 38.5 \%$, and $100 \%$ sunlight respectively. Under $10.3 \%$ and $38.5 \%$ sunlight, the device efficiency 
reached $7.0 \%$ and $7.3 \%$, respectively. The increase of short circuit current density with different film thickness is confirmed using the incident photon-to-current conversion efficiency (IPCE) spectrum; the spectrum becomes broader in the sequence $6<6+6 s<12<12+6$ s. The IPCE spectrum of a device using dye $\mathbf{1 3}$ with $12+6 \mathrm{~s}$ exhibits the broad absorption range starting from the $800 \mathrm{~nm}$ and a higher plateau at $67 \%(\lambda=495 \mathrm{~nm})$ (Figure 4$)$.

In summary, we have developed a simple one-step synthesis of dibromo DTT (4) from diester DTT (1) over $80 \%$ yield using one-pot bromo-decarboxylation for the DSCs dyes core unit. The organic DSCs dye DAHTDTT (13) consisted of TPA and DTT coupled with hexylthiophene showing high efficiency of $7.3 \%$ with $V_{\text {oc }}$ of $697 \mathrm{mV}, J_{\text {sc }}$ of $14.4 \mathrm{~mA} / \mathrm{cm}^{2}$, and $f f$ of 0.73 .

\section{EXPERIMENTAL SECTION}

Preparation of DAHTDTT (13). A solution of aldehyde 12 (80 mg, $0.09 \mathrm{mmol})$ in a mixture of acetonitrile $(10 \mathrm{~mL})$ and $\mathrm{CHCl}_{3}(10 \mathrm{~mL})$ with an excess of cyanoacetic acid (153 $\mathrm{mg}, 1.8 \mathrm{mmol})$ and piperidine $(0.1 \mathrm{~mL})$ was heated to $100{ }^{\circ} \mathrm{C}$ in a microwave reactor for 20 min. The reaction mixture was extracted with $\mathrm{CH}_{2} \mathrm{Cl}_{2}$ and the combined organic extracts were washed with $1 \mathrm{~N} \mathrm{HCl}$, water, and brine solution. The organic layer was dried over $\mathrm{MgSO}_{4}$. After removal of the solvent, the residue was purified by column chromatography on silica gel eluting with dichloromethane/methanol/acetic acid (in the volume proportions $10 / 1 / 0$ to $10 / 1 / 0.1$ ) to give the organic dye 13 (70 mg, $87 \%$ yield) as a dark solid, m. p. $144{ }^{\circ} \mathrm{C}, R_{\mathrm{f}}=0.56$ (10:1:0.1 $\mathrm{CH}_{2} \mathrm{Cl}_{2} / \mathrm{MeOH} /$ Acetic acid) after trituration with pet. spirits $40-60{ }^{\circ} \mathrm{C}$ and $\mathrm{CH}_{2} \mathrm{Cl}_{2} \cdot{ }^{1} \mathrm{H}$ NMR $(500 \mathrm{MHz}$, DMSOd6): $\delta 0.84(6 \mathrm{H}, \mathrm{t}, J=7.0 \mathrm{~Hz}), 1.28(8 \mathrm{H}$, br m), $1.37(4 \mathrm{H}$, br m), 1.62-1.67 (4 H, br m), 2.75 (2 H, t, $J=7.5 \mathrm{~Hz}), 2.83(2 \mathrm{H}$, $\mathrm{t}, J=7.5 \mathrm{~Hz}), 6.88-6.93(3 \mathrm{H}, \mathrm{m})$ 7.02-7.07 (6 H, m), $7.11(1$ H, s), 7.24 (1 H, d, $J=16 \mathrm{~Hz}$ ), 7.32 (4 H, t, $J=7.5 \mathrm{~Hz}), 7.47$ (4 H, d, $J=8.5 \mathrm{~Hz}), 7.66(1 \mathrm{H}, \mathrm{s}), 7.89(1 \mathrm{H}, \mathrm{s}), 7.90$ (1 H, s), $8.36(1 \mathrm{H}, \mathrm{s}) .{ }^{13} \mathrm{C}$ NMR $\left(125 \mathrm{MHz}\right.$, DMSO- $d_{6}$ at $\left.50{ }^{\circ} \mathrm{C}\right): 14.6$, 22.7, 29.1, 29.2 29.3, 29.6, 30.1, 30.4, 31.7, 31.8, 117.5, 120.2, 120.4, 122.6, 123.3, 124.1, 125.0, 128.3, 128.8, 128.9, 129.7, 130.3, 130.7, 131.2, 131.7, 134.0, 135.2, 138.1, 141.0, 141.3, 142.0, 142.8, 142.9, 143.0, 143.7, 147.5, 147.6, 147.6, 164.0; m/z (EI) [rel. intensity] 892.2 [100, (M)+], 893.2 [60, $\left.(\mathrm{M}+\mathrm{H})^{+}\right], 894.2\left[20(\mathrm{M}+2 \mathrm{H})^{+}\right] . \mathrm{m} / \mathrm{z}(\mathrm{EI}): 892.2310 .\left[\mathrm{M}^{+}\right]$. Calcd. for $\mathrm{C}_{52} \mathrm{H}_{48} \mathrm{~N}_{2} \mathrm{O}_{2} \mathrm{~S}_{5}$ 892.2319. FT-IR (neat $\mathrm{cm}^{-1}$ ):2921, 1684, 1569, 1507, 1492, 1391, 1276, 1173, 696.

ACKNOWLEDGMENT We thank the Australian Research Council, the Australian Goverment [DIISR ISL (CG10059)] and the Victorian State Government DPI (SERD) and DBI (VSA SPF) Program VICOSC for financial support. We thank Drs Joseph Frey and Michael Armitage (University of Cambridge) for their early observations on the bromodecarboxylation reactions of DTTcarboxylic acids.

Supporting Information Available: Syntheses and spectra of 4, 9, 10, 12, and 13; device fabrication; DFT calculations. This material is available free of charge via the internet at http://pubs.acs.org.
(1) Mishra, A.; Fischer, M. K. R.; Bäuerle, P. Angew. Chem. Int. Ed. 2009, 48, 2474-2499.

(2) Oyama, Y.; Harima, Y. Eur. J. Org. Chem. 2009, 2903-2934.

(3) Ning, Z. J.; Tian, H. Chem. Commun. 2009, 5483-5495.

(4) Qin, H.; Wenger, S.; Xu, M.; Gao, F.; Jing, X.; Wang, P.; Zakeeruddin, S. M.; Grätzel, M. J. Am. Chem. Soc. 2008, 130, 9202-9203.

(5) Yang, H. Y.; Yen, Y. S.; Hsu, Y. C.; Chou, H. H.; Lin, J. T. Org. Lett. 2010, 12, 16-19.

(6) Tian, H. N.; Yang, X. C.; Chen, R. K.; Zhang, R.; Hagfeldt, A.; Sunt, L. C. J. Phys. Chem. C 2008, 112, 11023-11033.

(7) Wang, Z. S.; Cui, Y.; Dan-Oh, Y.; Kasada, C.; Shinpo, A.; Hara, K. J. Phys. Chem. C 2007, 111, 7224-7230.

(8) Neale, N. R.; Kopidakis, N.; van de Lagemaat, J.; Grätzel, M.; Frank, A. J. J. Phys. Chem. B 2005, 109, 23183-23189.

(9) Zeng, W. D.; Cao, Y. M.; Bai, Y.; Wang, Y. H.; Shi, Y. S.; Zhang, M.;Wang, F. F.; Pan, C. Y.; Wang, P. Chem. Mater. 2010, 22, 1915-1925.

(10) Bessho, T.; Zakeeruddin, S. M.; Yeh, C.-Y.; Diau, E. W.-G.; Grätzel, M. Angew. Chem. Int. Ed. 2010, 49, 6646-6649.

(11) Paek, S.; Choi, H.; Lee, C. W.; Kang, M. S.; Song, K.; Nazeeruddin, M. K.; Ko, J. J. Phys. Chem. C 2010, 114, 14646-14653.

(12) Ko, S.; Choi, H.; Kang, M. S.; Hwang, H.; Ji, H.; Kim, J.; Ko, J.; Kang, Y. J. Mater. Chem. 2010, 20, 2391-2399.

(13) Lin, L. Y.; Tsai, C. H.; Wong, K. T.; Huang, T. W.; Hsieh, L.; Liu, S. H.; Lin, H. W.; Wu, C. C.; Chou, S. H.; Chen, S. H.; Tsai, A. I. J. Org. Chem. 2010, 75, 4778-4785.

(14) Li, R. Z.; Liu, J. Y.; Cai, N.; Zhang, M.; Wang, P. J. Phys. Chem. B 2010, 114, 4461-4464.

(15) Fischer, M. K. R.; Wenger, S.; Wang, M. K.; Mishra, A.; Zakeeruddin, S. M.; Grätzel, M.; Bäuerle, P. Chem. Mater. 2010, 22, 1836-1845.

(16) Zhang, G. L.; Bala, H.; Cheng, Y. M.; Shi, D.; Lv, X. J.; Yu, Q. J.; Wang, P. Chem. Commun. 2009, 2198-2200.

(17) Daeneke, T.; Kwon, T.-H.; Holmes, A. B.; Duffy, N. W.; Bach, U.; Spiccia, L. Nat. Chem. 2011, 3, in press, DOI 10.1038/NCHEM.966

(18) Li, X. C.; Sirringhaus, H.; Garnier, F.; Holmes, A. B.; Moratti, S. C.; Feeder, N.; Clegg, W.; Teat, S. J.; Friend, R. H. J. Am. Chem. Soc. 1998, 120, 2206-2207.

(19) Wang, L.; Chen, Q.; Pan, G. B.; Wan, L. J.; Zhang, S. M.; Zhan, X. W.; Northrop, B. H.; Stang, P. J. J. Am. Chem. Soc. 2008, 130, 13433-13441.

(20) Zhang, L.; Tan, L.; Wang, Z. H.; Hu, W. P.; Zhu, D. B. Chem. Mater. 2009, 21, 1993-1999.

(21) Zhan, X. W.; Tan, Z. A.; Zhou, E. J.; Li, Y. F.; Misra, R.; Grant, A.; Domercq, B.; Zhang, X. H.; An, Z. S.; Zhang, X.; Barlow, S.; Kippelen, B.; Marder, S. R. J. Mater. Chem. 2009, 19, 5794-5803.

(22) He, M. Q.; Li, J. F.; Sorensen, M. L.; Zhang, F. X.; Hancock, R. R.; Fong, H. H.; Pozdin, V. A.; Smilgies, D. M.; Malliaras, G. G. J. Am. Chem. Soc. 2009, 131, 11930-11938.

(23) Frey, J.; Bond, A. D.; Holmes, A. B. Chem. Commun. 2002, 2424-2425. (24) We thanks Drs J. Frey, S., Prommel and M. Armitage for first developing this method in the synthesis of DTT. See; Frey, J.; Prommel, S.; Armitage, M. A.; Holmes, A. B. Org. Synth. 2006, 83, 209-213.

(25) Chen, M. C.; Chiang, Y. J.; Kim, C.; Guo, Y. J.; Chen, S. Y.; Liang, Y. J.; Huang, Y. W.; Hu, T. S.; Lee, G. H.; Facchetti, A.; Marks, T. J. Chem. Commun. 2009, 1846-1848.

(26) Frisch, M. J.; Trucks, G. W.; Schlegel, H. B.; Scuseria, G. E.; Robb, M. A.; Cheeseman, J. R.; Montgomery, J. A. J.; Vreven, T.; Kudin, K. N.; Burant, J. C.; Millam, J. M.; Iyengar, S. S.; Tomasi, J.; Barone, V.; Mennucci, B.; Cossi, M.; Scalmani, G.; Rega, N.; Petersson, G. A.; Nakatsuji, H.; Hada, M.; Ehara, M.; Toyota, K.; Fukuda, R.; Hasegawa, J.; Ishida, M.; Nakajima, T.; Honda, Y.; Kitao, O.; Nakai, H.; Klene, M.; Li, X.; Knox, J. E.; Hratchian, H. P.; Cross, J. B.; Adamo, C.; Jaramillo, J.; Gomperts, R.; Stratmann, R. E.; Yazyev, O.; Austin, A. J.; Cammi, R.; Pomelli, C.; Ochterski, J. W.; Ayala, P. Y.; Morokuma, K.; Voth, G. A.; Salvador, P.; Dannenberg, J. J.; Zakrzewski, V. G.; Dapprich, S.; Daniels, A. D.; Strain, M. C.; Farkas, O.; Malick, D. K.; Rabuck, A. D.; Raghavachari, K.; Foresman, J. B.; Ortiz, J. V.; Cui, Q.; Baboul, A. G.; Clifford, S.; Cioslowski, J.; Stefanov, B. B.; Liu, G.; Liashenko, A.; Piskorz, P.; Komaromi, I.; Martin, R. L.; Fox, D. J.; Keith, T.; Al-Laham, M. A.; Peng, C. Y.; Nanayakkara, A.; Challacombe, M.; Gill, P. M. W.; Johnson, B.; Chen, W.; Wong, M. W.; Gonzalez, C.; Pople, J. A. Gaussian, Inc., Pittsburgh PA, 2003. 